\title{
Beyond Sexual Binaries? The German Federal Constitutional Court and the Rights of Intersex People
}

\section{H Botha*}

\section{P.E.R}

Pioneer in peer-reviewed, open access online law publications

Author

Henk Botha

Affiliation

Stellenbosch University

South Africa

Email

hbotha@sun.ac.za

Date of submission

17 March 2018

Date published

11 December 2018

Editor Dr A Gildenhuys

How to cite this article

Botha $\mathrm{H}$ "Beyond Sexual Binaries? The German Federal Constitutional Court and the Rights of Intersex

People" PER / PELJ 2018(21) - DOI http://dx.doi.org/10.17159/1727-

$3781 / 2018 / v 21 i 0 a 4747$

\section{Copyright}

\section{DOI}

http://dx.doi.org/10.17159/1727-

3781/2018/v21i0a4747

\begin{abstract}
In a recent judgment, the German Federal Constitutional Court held that it was unconstitutional to require every person's sex to be entered on the birth register, without providing for a third option for intersex persons. This article examines the intersex judgment in view of the Court's earlier jurisprudence on the rights of trans persons. It argues that this judgment was enabled, to a significant extent, by the fluid understanding of sex and gender identity shown in those judgments, and by the elaboration in those cases of the relationship between sexual freedom, human dignity and equality. It also comments on the possible relevance of the intersex judgment for South Africa, in view of some of the parallels and differences between German and South African constitutional jurisprudence.
\end{abstract}

\section{Keywords}

German Federal Constitutional Court; intersex; transsexual and transgender; sex and gender identity; human dignity, equality and freedom; sexual minorities in South Africa. 


\section{Introduction}

In a judgment delivered in October 2017 (hereafter the "intersex judgment"), the First Senate of the German Federal Constitutional Court (hereafter "the GFCC") held that it was unconstitutional to require every person's sex to be entered on the birth register, without providing for a third option for intersex persons. ${ }^{1}$ The judgment has been hailed as a milestone in the protection of intersex persons, which constitutes a radical challenge to binary conceptions of sex and gender. ${ }^{2}$ Despite the novelty of the judgment, I argue in this article that it shows certain continuities with some of the Court's earlier judgments in cases dealing with the rights of trans persons. ${ }^{3}$ First of all, the fluid understanding of sex and gender identity shown in these judgments arguably helped pave the way for the recognition of a third gender. ${ }^{4}$ Secondly, the intersex judgment drew on the Court's elaboration in these cases of the importance of sexual intimacy and self-determination as ingredients of the constitutional right to the free development of the personality, read with the constitutional guarantee of human dignity. It also

* Henk Botha. BLC LLB (Pretoria) LLM (Columbia) LLD (Pretoria). Department of Public Law, Stellenbosch University, South Africa. Email: hbotha@sun.ac.za. I am indebted to the National Research Foundation and the Alexander von Humboldt Foundation for financial assistance. Thanks to Christoph Möllers for his hospitality during a research stay at Humboldt University, Dominik Steiger and Jelena Bäumler for helpful conversations, Johndré Barnes for research assistance, and the anonymous referees for helpful comments. The responsibility for errors remains my own.

11 BvR 2019/16, judgment of 10 October 2017 (hereafter the "intersex judgment").

2 See generally Mangold 2017_http://verfassungsblog.de/nichtmann-nicht-frau-nichtnichts-ein-verfassungsblog-symposium.

$3 \quad$ I use the term "trans" to refer both to transsexual and transgender persons.

$4 \quad$ A brief note on my use of the terms "sex" and "gender": I recognise that a conflation of terms like sex, gender and sexual orientation can have devastating consequences for sexual minorities. This would be the case where gender is conflated with crude biological notions of sex, for example where the marriage of a trans person who underwent surgery to become a woman is not recognised because she cannot bear children, or where a trans person's sexual orientation is used to determine his or her sex or gender. See Visser and Picarra 2012 SAJHR 508-510, 530-531. However, the traditional way of distinguishing between sex and gender has itself been the subject of criticism. Some feminists and queer theorists point out that the idea that sex is something wholly natural or biological, whereas gender refers to the cultural meanings, roles and expectations associated with sex, hides the extent to which sex itself is culturally and discursively constructed. Butler Gender Trouble 10-12. It would therefore be a mistake to assume that the legal classification of intersex persons deals solely with questions of sex and is unrelated to gender. To do so, would be to revert to a dangerous essentialism, which reduces complex legal, moral and social questions to technical medical issues. The GFCC's intersex judgment itself recognises that the sex description of intersex persons cannot and should not be separated from their gender identity. For these reasons, I often refer to sex and gender (or sex and gender identity) together, rather than trying to separate them strictly. 
relied on the understanding of the relationship between freedom, dignity and equality developed in the trans judgments.

The article starts with a summary of the most salient aspects of the intersex judgment. It then considers the Court's understanding of sex and gender identity in that judgment and in the earlier trans cases. Next, it examines the understandings of freedom, and of freedom's relationship with dignity and equality, which inform those judgments. After that, it comments briefly on the possible relevance of the intersex judgment for South Africa, with reference to some of the parallels and differences between German and South African constitutional jurisprudence. The article ends with tentative observations on the transformative possibilities - and limits - of the judgments under discussion.

\section{The intersex judgment}

The case concerned a challenge to the constitutionality of a provision in the Civil Status Act (Personenstandsgesetz) of 2007, in terms of which a child's gender must be entered onto the birth register. In cases where neither a male nor a female gender can be assigned, an entry can be made without specifying the child's gender. The complainant in this case had, on the basis of a chromosome analysis, requested the registration office to amend the gender assigned to her at birth from "female" to "inter/diverse", or alternatively "diverse". The request was rejected on the ground that the legislation did not make provision for a third gender. Even though the legislation had been amended to create the possibility to leave a person's gender unspecified, it did not provide for a third option such as intersex or diverse. After several unsuccessful court challenges, the complainant approached the GFCC. The challenge rested on two grounds. First, it was argued that the refusal to allow a third option, besides male and female, violated the right to free development of the personality in terms of article $2(1)$, read with the guarantee of human dignity in article 1(1) of the Basic Law. Secondly, it was contended that it constituted discrimination based on sex, in contravention of article 3(3), and infringed the right to equality before the law, as guaranteed in article 3(1).

The GFCC referred in its judgment to the history of the legislative amendment that created the possibility of not entering a person's gender on the birth register. The UN Committee on the Elimination of Discrimination against Women, in its comment of 12 February 2009, requested Germany to enter into a dialogue with NGOs representing intersex and trans people in order to get a better understanding of their claims and to take effective 
action to protect their human rights. The government then asked the German Council for Ethics to draft a report on the position of intersex persons in Germany. The Council concluded in its report that forcing intersex persons to be categorised as either male or female violated their personality right and right to equal treatment. It recommended the creation of a third gender category, referred to as "other", and made recommendations relating to the amendment of a person's gender entry. It further submitted that the ends sought to be achieved through the recording of a person's gender on the birth register needed to be examined in order to establish whether it was at all necessary. The federal government committed itself to addressing these issues, but was of the opinion that they were too complex to be resolved in the short term. A provision was added to the Civil Status Act, which made it possible to leave a person's gender unspecified, and a process was envisaged to consider introducing more comprehensive changes. ${ }^{5}$

The Court held that article 2(1), read with article 1(1) of the Basic Law, protects the gender identity of persons who can be classified as neither male nor female. ${ }^{6}$ Article 2(1), which guarantees the right to the free development of the personality, entails both a general right to freedom and a general personality right. The latter seeks inter alia to secure the basic conditions under which persons can develop their individuality. ${ }^{7}$ The Court noted that gender classification is of central significance for every person's selfunderstanding and for how they are perceived by others. ${ }^{8}$ To require every person to be registered as either male or female is to deprive those who fall outside of that binary of the opportunity to be identified in a way which corresponds to their gender identity. The failure to provide for them is not rectified through the option of leaving a child's gender unspecified, or of subsequently scrapping their gender classification. Far from giving positive recognition to an alternative gender identity, such an entry creates the impression that those concerned are lacking in gender, or that their gender identity has not been clarified yet. ${ }^{9}$ The law thus has a negative impact on the development of the personality of intersex persons who do not identify as either male or female. Given the central importance of the Civil Status Act to a person's legally relevant identity, the Court held that the requirement of gender identification on the birth register, together with the failure to provide a third option which corresponds more closely to their gender

See the discussion at paras 3-7 of the intersex judgment.

Paragraph 36 of the intersex judgment.

Paragraph 38 of the intersex judgment.

Paragraph 39 of the intersex judgment.

Paragraph 43 of the intersex judgment. 
identity, violates the right to the free development of their personality. It impairs their ability to remain true to their gender identity in public and to be recognised by others for who they are. ${ }^{10}$

The Court further held that the failure to provide for a third gender amounts to discrimination based on sex. Article 3(3) of the Basic Law protects not only men and women against gender discrimination, but also persons who do not identify themselves as male or female. ${ }^{11}$ That is despite the fact that article 3(2) refers specifically to the equal rights of men and women, and that it is unlikely that the framers of the constitution in 1949 envisaged the recognition of a third gender. ${ }^{12}$ The Court also rejected the argument that the failure to include "gender identity" in article 3(3) points to an intention not to proscribe discrimination against those who do not identify themselves as male or female. The reason why gender identity was not added to the list of grounds of discrimination through a constitutional amendment was that it was believed to have been covered already by the reference to "sex". ${ }^{13}$ The impugned provisions treat such persons unequally to the extent that, unlike men and women, they cannot be registered in accordance with their gender. They must be registered as either male or female, even if they do not identify with those designations, or be consigned to an entry which creates the impression that they are genderless. ${ }^{14}$ The Court stated that article 3(3) is aimed at protecting members of groups that are endangered by structural discrimination, and that persons who identify neither with a male nor with a female gender identity experience high levels of vulnerability in a society in which gender tends to be thought of in binary terms. ${ }^{15}$

The limitation of articles 2(1) and 3(3) was found to be unjustified. In the first place, the Court held that the Basic Law itself does not entrench a strictly binary conception of sex or gender. Even though article 3(2) speaks of "men" and "women", and promotes the elimination of discrimination against women, it does not rule out alternative approaches to the relationship between gender and civil status. It neither necessitates treating gender as a component of civil status, nor opposes the recognition of a gender identity

\footnotetext{
10 Paragraphs $45-48$ of the intersex judgment.

Paragraphs 56, 58 of the intersex judgment.

Paragraphs 60, 61 of the intersex judgment.

Paragraph 62 of the intersex judgment. Art 3 was amended in 1994, when sentences were added to arts 3(2) and 3(3). The former obliges the state to promote the actual implementation of equal rights for men and women, while the latter prohibits disfavouring any person because of disability.

14 Paragraph 57 of the intersex judgment.

15 Paragraph 59 of the intersex judgment.
} 
beyond male and female. ${ }^{16}$ Secondly, the limitation cannot be justified with reference to the interests of third parties. The recognition of a third gender would not in any way affect the status of persons - including ones whose sexual development is atypical - who identify themselves as male or female. The idea is not to force anyone to identify with a third gender, but rather to increase the number of options available to persons with different variations of sexual development. ${ }^{17}$ Thirdly, the limitation cannot be justified with reference to the bureaucratic and financial costs involved in enabling other gender categories. The legislature in any event also has the option of relinquishing gender as a determinant of civil status, which would involve no additional costs. ${ }^{18}$ Finally, enabling alternative gender options is not precluded by the state's interest in maintaining order. It is true that, in a system in which gender plays a role in the legal classification of persons and the attribution of rights and duties, uncertainties could arise as a result of the introduction of a third option. However, such difficulties already exist where, as in Germany, the option exists of leaving a person's gender unspecified. ${ }^{19}$

The Court gave the legislature until 31 December 2018 to come up with a new arrangement. It emphasised that there are a number of options that could be considered. These include dispensing with a gender entry altogether, or creating the option of a third gender category beyond male and female. The Court made it clear that, if the latter option were to be chosen, the existing possibility of leaving one's gender open should also be retained. ${ }^{20}$

\section{Sex and gender identity}

What is most striking about this judgment is its rejection of a binary understanding of sex, in terms of which all persons are to be identified as either male or female. In the Court's view, the right to the free development of the personality, together with the guarantee of human dignity, entitles all persons to be identified in a way that corresponds to their gender identity, whether that is male, female or something else. Moreover, discrimination on the ground of sex is given a wide interpretation to include discrimination

Paragraph 50 of the intersex judgment.

Paragraph 51 of the intersex judgment.

Paragraph 52 of the intersex judgment.

Paragraphs 53-54 of the intersex judgment.

Paragraphs 51,65 of the intersex judgment. 
against persons whose gender identity cannot be captured in terms of the male/female binary.

The recognition of a third gender is a new departure, which could have farreaching implications for a legal system in which gender is an important determinant of personal status and the rights and obligations flowing from that status. Even though the Court, in a series of judgments, upheld the right of trans persons to sexual self-determination, these judgments still took the idea of a binary system of sexual classification for granted. ${ }^{21}$ Despite this, that jurisprudence helped lay the groundwork for the Court's reasoning in the intersex judgment. The trans judgments are characterised by a fluid understanding of sex and gender, which recognises that it is not simply a matter of a person's physical sexual attributes. In the first of these judgments, the Court held that trans persons who have undergone sexchange operations are entitled to an amendment of the original entry of their gender in the birth register. The judgment noted that the view that a person's sex can be determined purely on the basis of bodily sexual characteristics, and that it is something inborn and unvarying, is questionable in view of medical findings relating to psychosexuality. It stated that it is scientifically proven that there is a wide variety of forms of somatic intersexuality, and that there are individual cases in which there is a strong disassociation, as far as a person's sex is concerned, between form and actuality, or between a person's physiological and psychological makeup. ${ }^{22}$ Despite its rejection of a strictly binary approach, the Court nevertheless held on to certain essentialist assumptions, some of which were rejected in subsequent cases. For example, it stated that trans individuals simply wish to bring their physiological reality in accordance with their psychological makeup, that they are not interested in having same-sex relationships, and that, once their sex has been altered through surgery, they want to be able to have intercourse with a partner of the opposite sex. ${ }^{23}$

In subsequent cases, the Court stressed the importance of enabling trans persons to experiment with new gender roles before they decide to have sex-change operations. For instance, it held that a legislative provision which allows trans persons to effect a name change to reflect their own experienced gender identity was unconstitutional to the extent that it excluded persons under the age of 25. The Court reasoned that it is particularly important for young trans individuals to be able to assume new

See eg BVerfGE 128, 109 (2011) paras 60-62, 70, 72.

BVerfGE 49, 286 (1978) paras 50-51.

Paragraphs 52, 54 of the intersex judgment. 
gender roles, to gain confidence and to be shielded in the workplace and everyday life from stressful situations arising from the discrepancy between their official gender classification and how they experience their gender identity. ${ }^{24}$ In other cases, too, it emphasised that gender depends not only on persons' physical characteristics but also on their psychological makeup and own experienced gender. ${ }^{25}$

The Court also disowned its previous reasoning concerning the relationship between gender identity and sexual orientation, and held that persons' sexual orientation cannot be used to determine their gender. It accordingly invalidated a provision in terms of which trans persons whose name had been changed forfeited the changed name which reflected their own experienced gender identity upon entering into a legally recognised union with someone of the same sex. (For instance, in terms of this provision a trans person whose gender classification on the birth register was male, but who identified with the female sex and adopted a female name, had to revert back to the original male name upon marrying a woman.) It noted that, according to scientific research, a significant percentage of trans persons prefer same-sex over heterosexual relations. The assumption that a turn to same-sex relations casts doubt on a person's transsexuality is not warranted. ${ }^{26}$ The Court further pointed out that the differentiation in question between trans persons who did and did not undergo sex-change surgery rested on the assumption that all trans individuals experience their genitals as an error of nature which can be corrected only through a sex-change operation. This assumption is no longer tenable. Recent scientific findings show that the question whether a sex-change operation is required cannot be answered on the basis of broad generalisations, but must be determined within the context of each individual case. ${ }^{27}$

These later judgments show a keen awareness of the variability of sex, gender identity and sexual orientation. Far from portraying trans people as a homogeneous group, the judgments recognise that they are characterised by a variety of attitudes and needs relating to whether or not to undergo a sex-change operation, the sex of their partners, etc. This growing sensitivity to the diversity of the experiences and identities of trans people arguably helped pave the way for the recognition of a third gender beyond male and female. Once it is recognised that transsexuality comes in many different

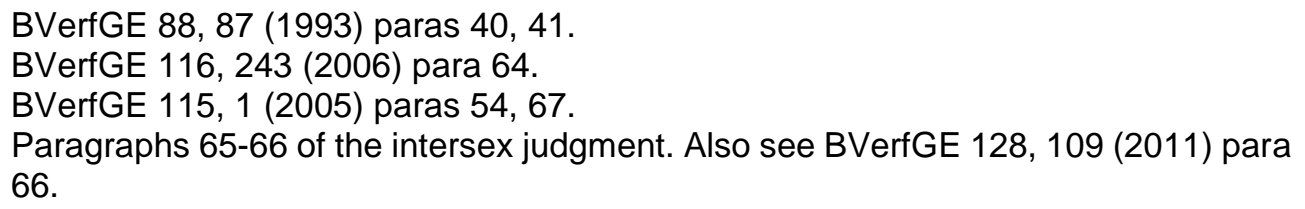


shapes and is not simply an accident of nature which is, in all cases, to be rectified through surgery, it becomes easier to see sex and gender identity in terms of a spectrum, rather than a sharp male/female dichotomy. From there, it is perhaps not such a long stretch to recognising that there are individuals who do not fit into either of these categories, and that new categories may need to be invented. In accordance with this emphasis on diversity, the third gender mooted by the Court in its 2017 judgment is itself characterised by a wide variety of internal differences. Referring as it does to intersex people, it includes individuals who, for a diversity of reasons, fall outside the typical definitions of male or female. These reasons include sexual or reproductive organs that do not fit the usual definitions of male or female, a discrepancy between sex organs and chromosomes or between internal and external sex organs, and unusual chromosome configurations. ${ }^{28}$

A second parallel between the Court's trans and intersex judgments lies in the emphasis on personal experience and choice. In the trans cases the Court held that persons' physical characteristics, psychological makeup and own experience of gender identity all play a role in determining their gender. In the intersex judgment it stressed that if legislation were to create a third gender category, intersex persons should, in addition to that option, be given the choice to be classified as male or female. These acknowledgments of the importance of personal experience and choice are not tantamount to a denial of the biological, social and environmental factors which limit the capacity of individuals to develop their personality and exercise freedom. The judgments are characterised by a keen awareness of the vulnerability of members of sexual minorities, and the need for the state to create an environment in which their freedom can flourish. On this view, respect for the dignity, equality and freedom of sexual minorities can be safeguarded only through laws that secure equal recognition for different forms of sexuality. Freedom is conceived in relational, not metaphysical terms: it depends on laws and structures of recognition that allow individuals, including those who are differently sexed, to assume different sexual roles and identities, and that recognise their intrinsic dignity and worth irrespective of their sex, gender or sexual orientation. ${ }^{29}$

See Anon Date Unknown https://medlineplus.gov/ency/article/001669.ht Intersex Society of North America Date Unknown http://www.isna.org/faq/what_is_intersex. freedom, see Cornell At the Heart of Freedom 64; Bishop and Woolman "Freedom and Security of the Person" 40/11-40/15. 


\section{Dignity, equality and freedom}

In the intersex judgment the GFCC held that the requirement that every person must be registered as either male or female was inconsistent with the constitutional guarantees of the free development of the personality, human dignity and equality. These three constitutional provisions also featured prominently in the trans cases. A number of laws and/or decisions were found to violate article 2(1) (free development of the personality), together with article 1(1) (human dignity). These included the failure to amend the gender entry of a trans person who had a sex-change operation on the birth register, ${ }^{30}$ and a provision in terms of which trans persons forfeited their changed name upon entering a same-sex relationship. ${ }^{31}$ The requirement that married trans persons who had a sex-change operation had to get divorced in order to gain official legal recognition of their changed sex, was invalidated on the same grounds. ${ }^{32}$ The same goes for the requirement that a trans person should have had a sex-change operation and be incapable of reproduction in order to qualify to enter a same-sex civil union. 33

Violations of article 3(1) (equality before the law) were found where certain categories of trans persons were excluded from benefits under the Transsexual Act (Transsexuellengesetz) of 1980. Two of these cases dealt with age restrictions: in the first, trans persons under the age of 25 could not have their gender changed on the birth register, even if they had a sexchange operation and complied with all the other requirements, ${ }^{34}$ while in the second, persons under 25 were excluded from the right to effect a name change. ${ }^{35}$ In a third case, some categories of foreigners who were legally and not only temporarily in Germany were barred from changing their name or gender. ${ }^{36}$ In all three cases, articles 1(1) and 2(1) featured prominently in the Court's reasoning. The impact of the restrictions on the human dignity and right to the free development of the personality of young trans persons played an important part in determining the level of scrutiny and the margin of discretion left to the legislature. The Court held that the more the unequal treatment of different groups of persons restricts those affected in the exercise of constitutionally guaranteed freedoms, the more difficult it

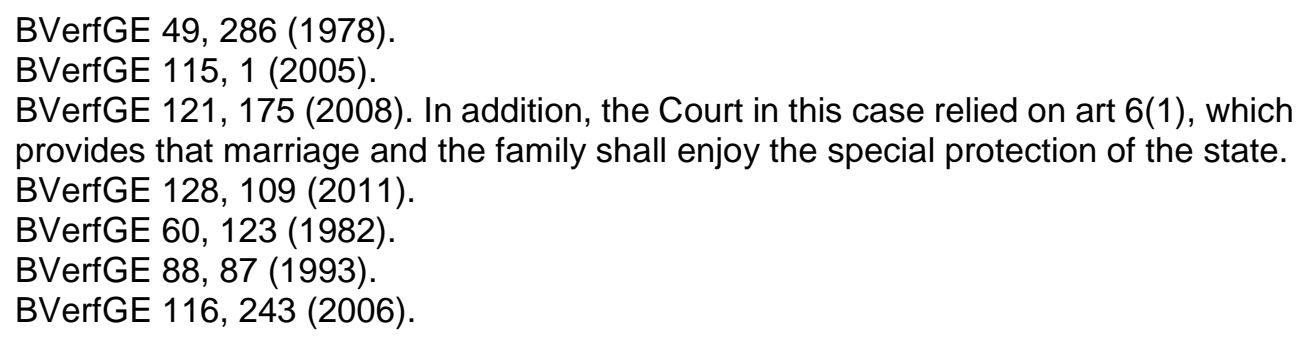


becomes to justify the measures in question. Where, as in these cases, they have a fundamental impact on the personality rights and capacity for selfactualisation of certain categories of people, a strict form of scrutiny is called for. ${ }^{37}$

The right to the free development of the personality thus plays a central part in cases involving the rights of sexual minorities. It does so as a selfstanding right, in combination with the constitutional guarantee of human dignity, and in helping to determine the intensity of scrutiny under the equality clause. In the view of the Court, article 1(1) protects the dignity of a person as she becomes aware of and understands herself as an individual. ${ }^{38}$ Article 2(1), together with article $1(1)$, protects the narrow personal sphere of life, including the intimate sexual sphere, which comprises the right to sexual self-determination. It thus also refers to discovering and recognising one's own gender identity and sexual orientation. ${ }^{39}$

This has important implications for a person's civil status and the rights and duties flowing from that status. First of all, individuals have the right to be assigned a gender which takes account of their physical characteristics as well as their psychological makeup and own experienced gender. ${ }^{40}$ Secondly, they are entitled to respect for their name. A name is both a means through which individuals discover their identity and develop their individuality, and an expression of their experienced and acquired gender identity. ${ }^{41}$ To require trans persons to be known by names which do not correspond to their gender identity as they experience it violates their right to sexual self-determination. It also intrudes into their intimate sphere, as it highlights the discrepancy between their official gender and the gender with which they identify, and forces them to reveal their transsexuality to third parties. ${ }^{42}$ Thirdly, article 2(1), in combination with article 1(1), guarantees the right to enter into a permanent intimate relationship with a person of one's choice, and to secure legal recognition for that relationship. ${ }^{43}$ In the view of the Court, reserving the institution of marriage for opposite-sex couples and the civil union for couples who share the same sex serves

BVerfGE 60, 123 (1982) paras 40-42; BVerfGE 88, 87 (1993) paras 34-41; BVerfGE 116, 243 (2006) paras 58, 60. In the last-mentioned case, the Court held that the provision in question violated art 3(1) in combination with arts 2(1) and 1(1).

BVerfGE 49, 286 (1978) para 50.

BVerfGE 115, 1 (2005) para 47.

BVerfGE 49, 286 (1978) para 50; BVerfGE 115, 1 (2005) para 50.

BVerfGE 115, 1 (2005) para 48.

BVerfGE 116, 243 (2006) paras 64-65.

BVerfGE 128, 109 (2011) para 53. 
important objectives and is not in itself unconstitutional. However, it would violate the right to sexual self-determination and intimacy if individuals' sex, for the purpose of establishing whether they are entitled to marry or enter a civil union, were to be established solely with reference to their external sexual characteristics and without taking account of their own experienced gender, as confirmed by medical opinion. ${ }^{44}$

Fourthly, individuals are not to be placed in a situation in which they must sacrifice rights that are fundamental to their personhood in order to be true to their own experienced gender identity or sexual orientation. For instance, the Court held that it is impermissible to force trans persons who are gay or lesbian to choose between retaining a name that corresponds to their gender identity or entering into a legally recognised union with a person of their choice..$^{45}$ It is similarly unconstitutional to require married trans persons to get divorced in order to gain official legal recognition of their changed sex, as both gender identity and the decision to be married go to the existential core of the personal sphere of intimacy and self-determination. ${ }^{46}$ The Court further found that the requirement that trans persons must undergo a sexchange operation and must be permanently incapable of reproduction to be able to enter a same-sex civil union impermissibly places them before the alternative either to compromise their right to bodily integrity under article 2(2) or to get married, as opposed to entering a civil union. The problem with the second option is that marriage contradicts gay and lesbian trans persons' own experience of their gender and sexual orientation. The provision in question thus forces individuals to choose between their bodily integrity and their sexual self-determination and intimacy. ${ }^{47}$

These judgments place great emphasis on the right of individuals to shape their gender identities in accordance with their own experience and selfunderstanding. This is not simply a right to be left alone, but a right to positive legal recognition of every person's capacity for self-definition and self-realisation. Individuals are entitled to experiment with and embrace gender identities that defy mainstream norms, and to be recognised by others for who they are. From a legal perspective, who they are is to be determined not in terms of a rigid system of binary classifications, but with reference to their own embodied experience and self-understanding. The right of individuals to determine their own gender identity can be limited in pursuance of a legitimate objective and subject to the proportionality

\footnotetext{
$44 \quad$ BVerfGE 128, 109 (2011) para 54.

45 BVerfGE 115, 1 (2005) para 53.

46 BVerfGE 121, 175 (2008) paras 41, 53, 54, 60.

47 BVerfGE 128, 109 (2011) paras 55-58.
} 
principle. However, serious restrictions of the rights to sexual intimacy and self-determination are subject to a stringent standard of justification. ${ }^{48}$ Moreover, as is clear from the third gender judgment, the fact that some individuals may feel offended or threatened by the recognition of gender identities very different from their own cannot be used to justify limitations of the rights of sexual minorities. ${ }^{49}$

The judgments in question are characterised, first of all, by a radical understanding of sexual freedom. They refuse to inscribe the right to sexual self-determination into a binary system of gender classification or to condition it on conformity to dominant sexual norms. This construction of sexual freedom and the strict standard of justification applicable to limitations of the right to determine and shape one's own gender identity resemble Drucilla Cornell's notion of the imaginary domain. Cornell describes the imaginary domain as a heuristic device which can help us envisage a prior moral space of evaluation in which women and sexual minorities are included in the moral community of persons as an initial matter. ${ }^{50}$ Given their equivalent evaluation as sexed beings, women's subjectivity does not hinge on a comparison with men. Similarly, the selfdetermination of members of sexual minorities is not conditioned on their conformity to roles and subject positions that are steeped in heteronormativity. This opens up a space for sexual self-determination in which all individuals, irrespective of their sex, gender identity or sexual orientation, have the right to be the source of their own sexual selfpresentations.

Drawing on the idea of freedom articulated by Immanuel Kant, Cornell argues that this right is subject to only one condition: that a person must not infringe on the freedom of others to pursue their ends. She must harmonise her freedom with the freedom of others, and may resort to law to coerce others to "use their freedom in a way that harmonizes with her freedom". ${ }^{51}$ Freedom may therefore be limited in order to ensure the freedom of others. However, the freedom of some may not be restricted to perpetuate the privilege of others. That would be the case where, for example, certain forms of sexuality are outlawed or legal recognition is withheld from certain gender identities on the basis that they offend the sensibilities and tastes of some sections of society. What is at stake in these cases is not the freedom of

\footnotetext{
48 BVerfGE 60, 123 (1982) paras 40-42; BVerfGE 88, 87 (1993) paras 34-41; BVerfGE 116,243 (2006) paras 58, 60.

1 BvR 2019/16 (2017) para 51.

Cornell At the Heart of Freedom 14-15.

Cornell At the Heart of Freedom 18, 191.
} 
heterosexual men and women, but the privileging of their sexuality and gender identity at the expense of others. This negates the right of minorities to experience their sexuality and constitute their families differently, to do so openly, and to demand public recognition and equal support for their choices. Put differently, it denies them full recognition as members of the moral community, and results in a violation of the imaginary domain. ${ }^{52}$

A second characteristic of this jurisprudence is its recognition of the interrelatedness of freedom and vulnerability. On the one hand, the Court is sensitive to the vulnerability of individuals who experience their sexuality in non-binary ways, while living in a society in which a binary understanding of sex and gender is considered the norm. ${ }^{53}$ As a result, it is attentive to the capacity of laws and practices to impede the self-realisation of members of sexual minorities, even in cases where those laws and practices appear neutral from a heteronormative perspective. Hence, the Court held that laws that deprive individuals of legal recognition for the gender with which they identify, or of the right to choose a name that expresses their experienced gender identity, or of the right to enter a legally recognised union with the person of their choice, or that condition these rights on the sacrifice of other interests that are constitutive of their personhood, have a particularly severe impact on their dignity and capacity for self-actualisation.

On the other hand, the Court does not conceive freedom as an abstract property of individuals who are already autonomous, or as the absence of vulnerability. It sees it, rather, as something to be developed and nurtured through legal, social and economic arrangements that enable individuals to choose the kind of life that they have reason to value and to be true to their self-understanding. ${ }^{54}$ Moreover, it views freedom as something precarious, as it refers not to the autonomy of individuals whose identities are already fully formed, but to the chance to create a life that they can call their own from multiple and often contradictory experiences and struggles. To borrow again from Cornell, it could be said that on the Court's understanding, freedom is intimately connected to the processes through which persons individuate themselves. Those processes are characterised by vulnerability and require "legal, political, ethical, and moral recognition if [they are] to be effectively maintained". 55

$52 \quad$ Cornell At the Heart of Freedom 177.

53 In relation to the social power inherent in the enactment of gender classifications and its impact on sexual minorities, see Butler Performative Theory of Assembly 32-35.

54 See Sen Development as Freedom.

55 Cornell At the Heart of Freedom 64. 
Thirdly, the judgments in question articulate freedom with human dignity and equality. As mentioned above, the Court held, in many of these judgments, that there was a violation of article 2(1) (free development of the personality) in combination with article 1(1) (human dignity). It was further noted that these two provisions featured prominently in the Court's reasoning in cases decided on the basis of article 3 (equality). In addition, it could be argued that the Court's understanding of freedom in these cases is infused with the idea of equality. The right to freedom is sometimes relied on to entrench majoritarian norms, or to maintain the privilege of some at the expense of others. That happens not only in cases in which an appeal is made to the "right" of moral majorities not to be confronted with identities or relationships with which they are not comfortable, but also where it is debated whether certain "minority" rights should be recognised. For example, Völzmann points out that the right to the recognition of one's gender identity is sometimes treated as if it concerns only sexual minorities, when in fact the majority of the population already enjoy that freedom. She argues that the Court in the third gender judgment avoided this paternalistic mind-set, which is premised on assumptions about what is "normal", by relating freedom and equality to each other. ${ }^{56}$ Put differently, it is only by articulating freedom with the ideals of equality and equal human dignity that constitutional interpreters can hope to extricate freedom rights from legal and social hierarchies which confine the right to self-realisation to certain categories of persons. ${ }^{57}$

\section{Relevance for South Africa?}

How much persuasive value would the reasoning in the third gender judgment have if a similar case came before the South African courts? While a detailed comparison of the position in Germany and South Africa is beyond the scope of this article, it is worth pointing out that there are significant parallels between the German Basic Law and the South African Constitution. First, the South African Constitution not only treats human dignity, equality and freedom as foundational constitutional values, but also groups them together in a way which suggests that they are interdependent and mutually reinforcing. ${ }^{58}$ The Constitutional Court's jurisprudence

56 Völzmann $2017 \quad \mathrm{http} / / /$ verfassungsblog.de/gleiche-freiheit-fuer-alle-zurfreiheitsrechtlichen-begruendungdes-bverfg-in-der-entscheidung-zur-drittenoption/.

57 See Balibar Equaliberty for a fascinating account of the interdependence of freedom and equality.

58 Sections 1(a) (the Republic of South Africa is founded on the values of "human dignity, the achievement of equality and the advancement of human rights and freedoms"), 7(1) (the Bill of Rights "affirms the democratic values of human dignity, equality and freedom"), 36(1) (limitations of the rights in the Bill of Rights are 
confirms that these values are closely interconnected. The Court has held, for example, that human dignity and freedom are "inseparably linked";59 that the equal dignity of all human beings is at the heart of the prohibition of unfair discrimination; ${ }^{60}$ and that freedom and equality are closely related. ${ }^{61}$ Its jurisprudence thus lends itself to the idea that individuals have the right to shape their sexual personae in accordance with their own experience and the life they value; that this right should be enjoyed equally by all; and that its limitation should be subjected to rigorous standards of justification.

Admittedly, the South African Constitution differs from the German Basic Law to the extent that it does not contain an express guarantee of the right to free development of the personality. It could be argued that section 12 , which safeguards the right to freedom and security of the person, should be interpreted to confer a general right to freedom which is not dissimilar from article 2(1) of the German Basic Law. ${ }^{62}$ However, even if this possibility is rejected, other constitutional guarantees can and have been used to protect a sphere of individual self-determination that is not covered by the specific freedoms guaranteed in the Constitution. As Frank Michelman has shown, the Constitutional Court has given the rights to dignity and privacy a broad interpretation to protect individuals against interference with their decisional freedom. ${ }^{63}$ In addition, section $12(2)$, which protects the right to bodily and psychological integrity, including the rights to make decisions concerning

permitted only if they are "reasonable and justifiable in an open and democratic society based on human dignity, equality and freedom") and 39(1) of the Constitution of the Republic of South Africa, 1996 (the Bill of Rights must be interpreted to "promote the values that underlie an open and democratic society based on human dignity, equality and freedom"). Ferreira v Levin and Vryenhoek v Powell 19961 SA 984 (CC) para 49 (hereafter Ferreira).

60 President RSA v Hugo 19976 BCLR 708 (CC) para 41. Also see Prinsloo v Van der Linde 19976 BCLR 759 (CC) paras 31-33; Harksen v Lane 19981 SA 300 (CC) paras 46, 50, 51, 53 and 91-92. MEC for Education: KwaZulu-Natal v Pillay 20081 SA 474 (CC) paras 62-68 (hereafter Pillay).

The majority of the Constitutional Court in Ferreira decided against giving an expansive reading to $s$ 11(1) of the Interim Constitution of the Republic of South Africa Act 200 of 1993, which similarly guaranteed freedom and security of the person. However, its reasoning was tied, in important respects, to features of the Interim Constitution that have not been retained in the final Constitution (paras 173, 174,182 ). The Court also left open the possibility that a residual right to freedom may be recognised in certain areas (para 185). 
reproduction and to security in and control over one's body, guarantees important aspects of a person's right to sexual self-determination.

Secondly, the Constitutional Court has articulated dignity, equality and freedom with respect for sexual, religious and cultural difference. On this view, the recognition of the right of all persons to shape their individuality in accordance with their own ends presupposes respect for every individual's singularity and difference. This translates, inter alia, into the need for the legal recognition of different forms of sexuality and family formations, ${ }^{64}$ and a reasonable accommodation of the beliefs and customs of cultural and religious minorities. ${ }^{65}$ The emphasis on the importance of difference, both to the development of the individual personality and the health of democratic institutions, ${ }^{66}$ suggests that the Court may also be sympathetic to the claims of those who experience their gender in non-binary ways.

Thirdly, Parliament has adopted legislation which signals its understanding that trans and intersex persons are vulnerable classes of persons in need of protection. Section 2(1) of the Alteration of Sex Description and Sex Status Act 49 of 2003 provides that certain categories of persons may apply for an alteration of the description of their sex on the birth register. The section allows a person's sex to be changed on the birth register not only in cases where a sex-change operation has been performed, but also in three other cases: where a person's sexual characteristics have been altered by medical treatment other than surgery (such as hormone replacement therapy) or "by evolvement through natural development resulting in gender reassignment", or where a person is intersex. To that extent, it takes a more liberal position than the German legislation, which requires surgery for a person's sex to be changed on the birth register, even though it allows trans individuals who have not had such surgery to change their names. Moreover, a 2005 amendment to section 1 of the Promotion of Equality and Prevention of Unfair Discrimination Act 4 of 2000 specifies that "sex" as a ground of discrimination includes "intersex", and adds a definition of "intersex" as "a congenital sexual differentiation which is atypical, to whatever degree". It thus makes it clear that discrimination on the basis of sex refers not only to discrimination against men or women, but also to discrimination against persons whose sexuality cannot be captured in binary terms. This is an important development, particularly since this Act is

See National Coalition paras 22, 134; Minister of Home Affairs v Fourie 20061 SA 524 (CC) para 60.

65 Prince $v$ President of the Law Society of the Cape of Good Hope 20022 SA 794 (CC) paras 146-149, 155-156, 162, 170; Pillay paras 71-83.

66 Botha 2009 SAJHR 10-16. 
constitutionally required legislation, which was adopted in terms of section $9(4)$ of the Constitution to give effect to the constitutional right to equality. ${ }^{67}$

Problems remain, despite these indications of a shift on the part of the legislature towards the recognition of the rights of trans and intersex people. In certain respects, the Alteration of Sex Description and Sex Status Act remains steeped in assumptions that reflect dominant understandings of sexuality and gender and are at odds with the right to self-determination of sexual minorities. Perhaps most importantly, the alteration of a person's sex is still framed within binary terms, and does not provide a third option to those who identify as neither male nor female. In addition, the implementation of the Act leaves much to be desired. A study undertaken by Gender DynamiX and the Legal Resources Centre has identified several problems. These include the fact that, contrary to the provisions of the Act, the Department of Home Affairs sometimes rejects applications for the amendment of someone's sex on the basis that no proof was submitted that the applicant's sex had been changed through surgery. ${ }^{68}$ The study also points out that married applicants face a range of obstacles, which stem from the fact that neither the Marriages Act 25 of 1961 nor the Recognition of Customary Marriages Act 120 of 1998 provides for same-sex marriage. The Department of Home Affairs has consequently required married couples to get divorced and then remarry under the Civil Union Act 17 of 2006 in order for one of the spouses to change his or her sex on the marriage certificate. This would require them to claim an irretrievable breakdown of their marriage when, in fact, they wish to remain married. ${ }^{69}$ In a recent judgment, the Western Cape High Court held that this violated the spouses' rights to dignity, equality and administrative justice. ${ }^{70}$

The binary system of gender classification that is used in South Africa seems inconsistent with the constitutional vision of an open and democratic society based on human dignity, equality and freedom, which requires respect for the many differences between individuals. Different mechanisms could be considered to cure this apparent constitutional defect. The first is to provide the option of leaving a child's sex description open. This could introduce a greater measure of flexibility, but would arguably fail to provide

67 See Klein 2012 Ethnoscripts 1222 on the significance of the inclusion of intersex.

68 Gender DynamiX and Legal Resources Centre Date Unknown https://genderdynamix.org.za/wp-content/uploads/LRC-act49-2015-web.pdf 21-23.

Gender DynamiX and Legal Resources Centre Date Unknown https://genderdynamix.org.za/wp-content/uploads/LRC-act49-2015-web.pdf_24-29. The paper rightly points out at 27-28 that this creates a situation similar to the impact of the legislation that was declared unconstitutional in BVerfGE 121, 175 (2008). KOS v Minister of Home Affairs 20176 SA 588 (WCC). 
a positive gender identification to intersex persons who identify as neither male nor female. It would thus continue to treat them as an anomaly. The second alternative, namely the introduction of a third gender category, seems better able to protect the dignity, equality and freedom of intersex persons - particularly if it is done with a degree of flexibility, in a way that respects the choices of intersex individuals who identify as male or female. This mechanism could be combined with the first one, thus enabling intersex persons to choose between male, female, a third option such as "diverse", or leaving the sex description open. However, even this is not a magic cure, as is evident from some of the reactions to the legislative response to the GFCC's intersex judgment, as referred to below. Thirdly, abolishing gender registration is the most radical alternative, which would remove the law's complicity in the marginalisation of sexual minorities. However, it should be preceded by a careful study of the implications that it would have for a wide range of laws and legal fields.

\section{Concluding remarks}

The GFCC's judgment in the third gender case is a milestone in the protection of intersex persons, which could have an important destabilising effect on binary conceptions of sex and gender. I have argued in this article that in certain respects the groundwork for this judgment was laid in a series of earlier cases on the rights of trans persons. These judgments introduced a degree of fluidity into the Court's understanding of sex and gender identity. Admittedly, the first trans judgment was still marked by certain essentialist assumptions and by its treatment of trans persons as a fairly homogenous group. However, subsequent judgments showed greater sensitivity to the differences among those labelled as trans, and resisted the conflation of gender identity with sexual orientation. Even though these judgments took the existence of a binary system of gender classification for granted, they arguably also helped to erode it - by acknowledging the variability of sex, gender identity and sexual orientation, and by recognising that gender identity does not simply turn on a person's physical sexual characteristics, but that personal experience and choice also play a significant role. Viewed through this lens, the third gender judgment represents an important further step in the radicalisation of sexual difference. It is best read not as an attempt to resolve the inconsistencies caused by a binary system of gender classification through the introduction of a third, more or less stable category, but as a multiplication of options, an opening up of new possibilities of gender identification, and an enlargement of the space for different sexual imaginations. 
The third gender judgment's understanding of sexual freedom and its relationship with human dignity and equality also shows certain continuities with the trans judgments. I argued that the mutual articulation in these cases of dignity, equality and freedom resulted in a radical understanding of sexual self-determination. In the first place, the freedom to define one's own gender identity and sexuality is seen as a universal right which accrues to all individuals, regardless of whether or not they fit within a binary frame or conform to dominant sexual norms. Secondly, freedom is viewed not as the exclusive property of "self-sufficient" individuals, but as something that vests in every person, including those whose lives are marked by marginalisation, vulnerability and dependence. It denotes not the absence of vulnerability but, in the words of Lorraine Code, "climates of recognition" which will enable individuals to "live their vulnerabilities well". ${ }^{71}$ Respect for freedom requires laws that allow individuals to shape their individuality and develop their personality from their multiple and often contradictory commitments, experiences and struggles. Thirdly, freedom is distinguished from unjustified privilege, as sexual self-determination does not include the right to be shielded from the recognition of identities and sexualities different from one's own.

There are important parallels between the vision of sexual selfdetermination developed in the GFCC's judgments referred to above and South Africa's constitutional jurisprudence. South Africa's Constitution treats human dignity, equality and freedom as foundational values that are interrelated and interdependent. This vision requires all members of society, including those who are most marginalised and vulnerable, to have an equal right to shape their individuality in accordance with their own experience and understanding of what constitutes a good life. It also requires respect for every individual's singularity and difference. In addition, the South African legislature has recognised that trans and intersex persons are vulnerable minorities in need of protection. For these reasons, the GFCC's reasoning in cases concerning the rights of trans and intersex persons should have considerable persuasive force in South Africa.

Despite my positive appraisal of the GFCC's reasoning in these judgments, a healthy dose of realism is called for. The legislative response to the intersex judgment is a reminder that traditional conceptions of sex and gender identity have a powerful hold on the legal and political imagination. On 15 August 2018 the German cabinet approved a Bill which, in seeking to give effect to the intersex judgment, introduces a third category called

$71 \quad$ Code 2009 Philosophical Papers 328. 
"diverse". ${ }^{72}$ The Bill has drawn sharp criticism from organisations representing intersex and trans persons. One of the criticisms relates to the requirement that persons wishing to change their sex description must present medical evidence that confirms their intersex status. This is said to be at odds with the right of sexual self-determination, and with the GFCC's understanding that gender identity is not simply a matter of biological attributes, but also of a person's psychological makeup. Another criticism is that the government failed to take seriously the alternative option referred to by the Court, namely to scrap the sex entry. Critics point out that the reason offered by the government for not taking this option, namely that it would affect individuals' ability to prove their identity, is unconvincing. In the view of some gender activists and organisations, the abolition of gender registration is the only way in which sexual self-determination and equality can truly be realised. ${ }^{73}$

In a society in which binary gender identities are considered the norm, trans and intersex persons face serious threats to their freedom, personhood and bodily and psychological integrity. Many intersex persons are subjected to surgery at a young age, which could cause severe physical and psychological trauma. ${ }^{74}$ Trans persons whose name or sex entry in the birth register does not match their physical appearance are subjected to serious infringements of their privacy and could be refused a range of services, both in the public and private sectors. Moreover, in South Africa sexual minorities experience high levels of assault, rape and murder. ${ }^{75}$ It would be naïve to assume that these issues could be resolved simply by recognising the rights of trans people to choose their gender identity, or by introducing a third option. ${ }^{76}$ For as long as lawyers, public servants, health professionals and citizens view traditional assumptions about sexuality and gender as natural and necessary, these problems are bound to recur. At the same time, however, we should not underestimate law's potential to legitimate or help transform the sexual status quo. For centuries, legal rules normalised the idea that every person is either male or female, that a person's sex is

72 At the time of the finalisation of the article, the Bill still awaited Parliamentary approval.

73 Baars 2018 https://verfassungsblog.de/new-german-intersex-law-thirdgender-butnot-as-we-want-it/.

74 See Sloth-Nielsen 2018 Stell LR 48.

75 See Gender DynamiX and Legal Resources Centre Date Unknown https://genderdynamix.org.za/wp-content/uploads/LRC-act49-2015-web.pdf 10; Collison 2018 https://mg.co.za/article/2018-01-24-00-intersex-babies-killed-at-birthbecause-theyre-bad-omens/.

76 See Baars $2017 \mathrm{http}: / /$ verfassungsblog.de/the-politics-ofrecognition-and-the-limitsof-emancipation-through-law/. 
immutable and established at birth, and that it is an important determinant of an individual's rights and duties. While laws and judgments that reject these ideas are unlikely to effect a sudden and wholesale change in societal attitudes, they could have an important destabilising effect in the longer run, and help multiply the spaces within which resistance is possible.

Respect for the equal dignity and freedom of sexual minorities cannot be achieved simply through their formal inclusion within existing sexual roles and structures of recognition. Something more radical is needed, which shakes up existing distributions of sexual roles, transforms existing structures of recognition and opens up spaces in which multiple sexual imaginations and subject positions can flourish. That would require the deconstruction of sexual binaries and a decentring of the experiences of "straight" persons. ${ }^{77}$ Judgments like the one in the third gender case could provide significant impetus to such a radical form of sexual politics, particularly if they give rise to a thorough reconsideration of the role of sex and gender in the configuration of a person's civil status and the rights and duties flowing from that status. However, the obstacles remain formidable, given the hold of sexual binaries and heteronormative assumptions on our legal and political imagination.

\section{Bibliography}

\section{Literature}

Balibar Equaliberty

Balibar É Equaliberty: Political Essays (Duke University Press Durham 2014)

Bishop and Woolman "Freedom and Security of the Person"

Bishop M and Woolman S "Freedom and Security of the Person" in Woolman S, Bishop M and Brickhill J (eds) Constitutional Law of South Africa $2^{\text {nd }}$ ed (Juta Cape Town 2006) 40/1-40/99

Botha 2009 SAJHR

Botha H "Equality, Plurality and Structural Power" 2009 SAJHR 1-37

Butler Gender Trouble

Butler J Gender Trouble (Routledge New York 1990)

77 See Fraser "Social Justice" 75-76. 
Butler Performative Theory of Assembly

Butler J Notes toward a Performative Theory of Assembly (Harvard University Press Cambridge 2015)

Code 2009 Philosophical Papers

Code L "A New Epistemology of Rape?" 2009 Philosophical Papers 327345

Cornell At the Heart of Freedom

Cornell D At the Heart of Freedom: Feminism, Sex, and Equality (Princeton University Press Princeton 1998)

Fraser "Social Justice"

Fraser N "Social Justice in the Age of Identity Politics: Redistribution, Recognition, and Participation" in Fraser N and Honneth A (eds) Redistribution or Recognition? A Political-Philosophical Exchange (Verso London 2003) 7-109

Klein 2012 Ethnoscripts

Klein T "Who Decides whose Gender? Medico-Legal Classifications of Sex and Gender and their Impact on Transgendered South Africans' Family Rights" 2012 Ethnoscripts 12-34

Michelman "Freedom by any other Name?"

Michelman F "Freedom by any other Name? A Comparative Note on Losing Battles While Winning Wars" in Barnard-Naudé AJ, Cornell D and Du Bois F (eds) Dignity, Freedom and the Post-Apartheid Legal Order: The Critical Jurisprudence of Laurie Ackermann (Juta Cape Town 2009) 91-111

Sen Development as Freedom

Sen A Development as Freedom (Oxford University Press Oxford 1999)

Sloth-Nielsen 2018 Stell LR

Sloth-Nielsen R "Gender Normalisation Surgery and the Best Interest of the Child in South Africa" 2018 Stell LR 48-72

Visser and Picarra 2012 SAJHR

Visser C and Picarra E "Victor, Victoria or V? A Constitutional Perspective on Transsexuality and Transgenderism" 2012 SAJHR 506-531

\section{Case law}

1 BvR 2019/16, judgment of 10 October 2017 
BVerfGE 49, 286 (1978)

BVerfGE 60, 123 (1982)

BVerfGE 88, 87 (1993)

BVerfGE 115, 1 (2005)

BVerfGE 116, 243 (2006)

BVerfGE 121, 175 (2008)

BVerfGE 128, 109 (2011)

Dawood; Shalabi; Thomas v Minister of Home Affairs 20003 SA 936 (CC)

Harksen v Lane 19981 SA 300 (CC)

Ferreira v Levin and Vryenhoek v Powell 19961 SA 984 (CC)

KOS v Minister of Home Affairs 20176 SA 588 (WCC)

MEC for Education: KwaZulu-Natal v Pillay 20081 SA 474 (CC)

Minister of Home Affairs v Fourie 20061 SA 524 (CC)

National Coalition for Gay and Lesbian Equality v Minister of Justice 19991 SA 6 (CC)

President RSA v Hugo 19976 BCLR 708 (CC)

Prince v President of the Law Society of the Cape of Good Hope 20022 SA 794 (CC)

Prinsloo v Van der Linde 19976 BCLR 759 (CC)

\section{Legislation}

Alteration of Sex Description and Sex Status Act 49 of 2003

Basic Law for the Federal Republic of Germany

Civil Status Act (Personenstandsgesetz) of 2007

Civil Union Act 17 of 2006 
Constitution of the Republic of South Africa, 1996

Interim Constitution of the Republic of South Africa Act 200 of 1993

Marriages Act 25 of 1961

Promotion of Equality and Prevention of Unfair Discrimination Act 4 of 2000

Recognition of Customary Marriages Act 120 of 1998

Transsexual Act (Transsexuellengesetz) of 1980

\section{Internet sources}

Anon Date Unknown https://medlineplus.gov/ency/article/001669.htm Anon Date Unknown Intersex https://medlineplus.gov/ency/ article/001669. htm accessed 10 February 2018

Baars $2017 \mathrm{http}: / /$ verfassungsblog.de/the-politics-ofrecognition-and-thelimits-of-emancipation-through-law/

Baars G 2017 The Politics of Recognition and the Limits of Emancipation through Law http://verfassungsblog.de/the-politics-ofrecognition-and-thelimits-of-emancipation-through-law/ accessed 10 January 2018

Baars 2018 https://verfassungsblog.de/new-german-intersex-lawthirdgender-but-not-as-we-want-it/

Baars G 2018 New German Intersex Law: Third Gender but not as we want it https://verfassungsblog.de/new-german-intersex-law-thirdgender-but-notas-we-want-it/ accessed 20 November 2018

Collison 2018 https://mg.co.za/article/2018-01-24-00-intersex-babieskilled-at-birth-because-theyre-bad-omens/

Collison C 2018 Intersex Babies Killed at Birth because "They're Bad Omens" https://mg.co.za/article/2018-01-24-00-intersex-babies-killed-atbirth-because-theyre-bad-omens/ accessed 5 February 2018

Gender DynamiX and Legal Resources Centre Date Unknown https://genderdynamix.org.za/wp-content/uploads/LRC-act49-2015-

web.pdf

Gender DynamiX and Legal Resources Centre Date Unknown Briefing Paper: Alteration of Sex Description and Sex Status Act 49 of 2003 https://genderdynamix.org.za/wp-content/uploads/LRC-act49-2015web.pdf accessed 8 February 2018 
Intersex Society of North America Date Unknown http://www.isna.org/faq/what_is_intersex Intersex Society of North America Date Unknown What is Intersex? http://www.isna.org/faq/what_is_intersex accessed 10 February 2018

Mangold 2017 http://verfassungsblog.de/nichtmann-nicht-frau-nicht-nichtsein-verfassungsblog-symposium Mangold A 2017 Nicht Mann. Nicht Frau. Nicht Nichts: Ein VerfassungsblogSymposium http://verfassungsblog.de/nichtmann-nicht-frau-nicht-nichtsein-verfassungsblog-symposium accessed 10 January 2018

Völzmann 2017 http://verfassungsblog.de/gleiche-freiheit-fuer-alle-zurfreiheitsrechtlichen-begruendungdes-bverfg-in-der-entscheidung-zurdritten-option/

Völzmann B 2017 Gleiche Freiheit für alle! Zur freiheitsrechtlichen Begründung des BVerfG in der Entscheidung zur Dritten Option http://verfassungsblog.de/gleiche-freiheit-fuer-alle-zur-freiheitsrechtlichenbegruendungdes-bverfg-in-der-entscheidung-zur-dritten-option/ accessed 10 January 2018

\section{LIST OF ABBREVIATIONS}

GFCC

SAJHR

Stell LR
German Federal Constitutional Court South African Journal on Human Rights

Stellenbosch Law Review 